\title{
Use of Peroxide Value and Moisture Content as a Measure of Quality for Amaranth-Sorghum Grains Based Complementary Food
}

\author{
Anne Wanjiru Gichau ${ }^{1 *}$, Judith Kanensi Okoth ${ }^{1}$, Anselimo Makokha ${ }^{1}$ and George Wafula Wanjala \\ ${ }^{1}$ Department of Food Science and Technology, School of Food and Nutrition Sciences, Jomo Kenyatta University of Agriculture and technology, Nairobi, Kenya \\ ${ }^{2}$ Kenya Industrial Research and Development Institute, Food Technology Division, Nairobi, Kenya
}

*Corresponding author: Anne Wanjiru Gichau, Department of Food Science and Technology, School of Food and Nutrition Sciences, Jomo Kenyatta University of Agriculture and technology, Nairobi, Kenya. Tel: +254721495626; E-mail: annegicalf@yahoo.com

Received: 01 Oct, 2019 | Accepted: 25 Oct, 2019 | Published: 01 Nov, 2019

Citation: Gichau AW, Okoth JK, Makokha A, Wanjala GW (2019) Use of Peroxide Value and Moisture Content as a Measure of Quality for Amaranth-Sorghum Grains Based Complementary Food. Nutr Food Technol Open Access 5(2): dx.doi.org/10.16966/2470-6086.162

Copyright: (C) 2019 Gichau AW, et al. This is an open-access article distributed under the terms of the Creative Commons Attribution License, which permits unrestricted use, distribution, and reproduction in any medium, provided the original author and source are credited.

\begin{abstract}
Amaranth sorghum grains complementary food is a nutrient dense dry food product for infants and young children. It is prone to moisture absorption from the environment and fat oxidation depending on packaging and storage condition due to its low moisture content and high level of unsaturated fat. In this study, amaranth sorghum grains complementary food was stored in three types of packaging material namely, kraft paper, kraft paper with polyethylene lining and aluminium pouch being the commonly used packaging materials for dry complementary foods in Kenya. These packaged samples were stored at ambient, $25^{\circ} \mathrm{C}, 60 \%$ relative humidity and $35^{\circ} \mathrm{C}, 75 \%$ relative humidity for 180 days. The moisture content of the product and the peroxide value of the oil extracted from the product were determined using the standard methods at an interval of 45 days for 180 days. The initial peroxide value of the product at day zero was 0.48 meq $\mathrm{O}_{2} \mathrm{Kg}^{-1}$ while its moisture content was $3.7 \%$ on dry weight basis. Over the 180 days of storage, aluminium pouch was the most effective package in controlling increase in moisture content and peroxide value in comparison to the other two packages. Samples stored at $35^{\circ} \mathrm{C}, 75 \%$ RH had a shorter shelf life compared to those stored at $25^{\circ} \mathrm{C}, 60 \%$ RH and ambient conditions. It is recommended that the product should be stored below $25^{\circ} \mathrm{C}$ and packaged in aluminium pouch to achieve a longer shelf life.
\end{abstract}

Keywords: Peroxide value; Moisture content; Quality; Complementary food

\section{Introduction}

Food products normally undergo deterioration and spoilage during storage resulting from growth and activities of microorganisms, food enzymes activities and chemical reactions within the food [1]. These changes are majorly influenced by the intrinsic factors like water activity and nutrient content or extrinsic factors such as temperature, moisture, oxygen, light and physical stress [2]. Increased consumer demand for safe, fresh and high quality foods availed year round and the ongoing globalization of food distribution systems are some of the factors that have contributed to the improved shelf life by food industries. It has become an obligatory for the industries to ensure shelf life stability of products as they are transported from their source and during storage [2].

Shelf life determination is one of the most significant steps in production of food. Shelf life is defined as the period through which products keep satisfactory level of eating quality from a sensory and safety point of view [3]. Methods used in determination of storage time is dependent on product type [2,3]. Quality deterioration in food can be described based on a several compositional features like microbial level, concentration of reactive species, water activity,
pH among others [2]. Perishable foods for example are prone to microbial growth hence a good indicator of safety for such foods. For imperishable foods however, certain factors are related with nutritionally important compounds and may be used to determine shelf life of a product [3]. These factors may include chemical changes like fat oxidation, moisture content, physical changes and sensory evaluation. Shelf life determination can be done through conventional storage. This is where a product is stored for a long time under conditions such as expected during normal storage and selected parameters are tested periodically [3]. Another method is used is accelerate shelf life test where the product is stored in high temperature or exposed to high oxygen concentration and tests done on some selected indicators [3]. Then, kinetic procedures are used to evaluate the changes of the indicators.

Amaranth Sorghum grains based Complementary Food (ASCF) is made of $90 \%$ amaranth grains and $10 \%$ sorghum grains which are steeped, germinated, dried, extruded, milled and finally packaged [4]. It is a dry product with moisture content of $3.7 \%$ and is composed of $7.8 \%$ fat having $77 \%$ unsaturated fatty acids. Most packaged dry products are susceptible to moisture adsorption from the environment. They absorb moisture through the package when stored in humid 
environments, which can cause undesirable effects on shelf life [5]. For example, products inform of powder or crystalline can be clumped and biologically active chemicals hydrolyze after absorbing moisture. Such products that tend to absorb moisture from the environment are called "hygroscopic" [5]. The product is also high in unsaturated fatty acids, making it prone to oxidation. This may be an indication that the product has limited shelf life [6]. The key characteristics of packaging material for dry food products are barrier properties to water vapour, oxygen and light in addition to physical strength required to maintain the integrity of the package [5]. This is because of their sensitivity to water absorption, which causes significant changes in quality and texture. Packaging which permeates oxygen or light could initiate oxidation resulting to rancidity and related objectionable flavours in dry products with high fat content [7]. As a foodstuff intended for specific nutritional uses complementary foods for infants and young children conform to the set guidelines. Assessment of fat oxidation and moisture adsorption with storage is key for prediction of ASCF shelf life as they are principle indicators. The aim of the paper was to evaluate the shelf-life of ASCF based on fat oxidation and moisture absorption.

\section{Materials and Methods \\ Processing of ASCF}

Amaranth and sorghum grain were obtained from Bondo Farmers Marketing group (Western, Kenya). The grains were sorted to remove foreign material. The sorted grains were cleaned using clean drinking water then steeped, germinated and dried as described by Okoth JK, et al. [4] he rootlets of the dried grains of amaranth and sorghum were first removed before mixing the grains in the ratio of $90 \%$ amaranth and $10 \%$ sorghum. The mixture was extruded then milled in to flour as described by Okoth JK, et al. [4].

\section{Storage of ASCF}

ASCF product was subdivided into 200g samples and packaged either in kraft paper, kraft paper with polyethylene lining or aluminum pouch. The kraft paper with polyethylene lining and aluminum pouch were sealed using plastic vacuum sealer machine while kraft paper was sealed using a sealing tape. The packages containing each of the samples were then randomly selected and stored at three storage conditions namely, ambient, $25^{\circ} \mathrm{C}$ and $60 \% \mathrm{RH}$ or at $35^{\circ} \mathrm{C}$ and $75 \%$ RH. Peroxide value and moisture content were analyzed before storage as the base line and then after every 45 days over a period of 180 days.

\section{Determination of moisture content}

Moisture content was determined by oven drying according to Association of Official Analytical Chemist [8] methods, 925.09. The moisture dishes were washed and placed in an oven drier at $105^{\circ} \mathrm{C}$ for one hour. They were then placed in a desiccator to cool and the initial weight of the dishes recorded $\left(\mathrm{W}_{1}\right)$. Three grams of ASCF sample were taken and placed in the moisture dish and weight recorded $\left(\mathrm{W}_{2}\right)$. The dishes were then placed in an oven drier for 3 hours. After drying the moisture dishes with dried samples were removed from the oven drier, cooled in a desiccator and the final weight recorded $\left(\mathrm{W}_{3}\right)$. The percentage moisture content of the samples was calculated as shown below:

$$
\text { Moisture content }(\%)=\frac{\left(W_{3}-W_{1}\right)}{\left(W_{2}-W_{1}\right)} \times 100
$$

\section{Peroxide value analysis}

This was determined through iodometric titration according to standard methods for the oils analysis AOCS (1998) [9], and the results were expressed in meq $\mathrm{O}_{2} / \mathrm{kg}$ oil. Two grams of ASCF oil samples were weighed into $250 \mathrm{ml}$ stoppered conical flask. Thirty milliliter of acetic acid chloroform solvent mixture was added in each and swirled to dissolve. Then $0.5 \mathrm{ml}$ saturated potassium iodide solution was added with a mohr pipette and left to stand for 1 minute in the dark with occasional shaking then added about $30 \mathrm{ml}$ of distilled water. This was titrated with $0.01 \mathrm{~N}$ sodium thiosulphate solution, with vigorous shaking until yellow color was almost gone. $0.5 \mathrm{ml}$ starch solution was added as an indicator and titration was continued until the blue color disappeared indicating the end point. Calculation of the peroxide value was done as below:

$$
P V=\frac{\text { Titre } \times N \times 100}{W}
$$

Where $\mathrm{W}$ is the weight of the sample, Titre $=\mathrm{ml}$ of Sodium Thiosulphate used, N=Normality of sodium thiosulphate solution.

\section{Analysis of data}

All the experiments were arranged in a randomized block design with a factorial structure of main treatments of storage condition and packaging. The sub-treatments were the three types of packaging materials namely, kraft paper, kraft paper with polyethylene lining and aluminium pouch, the three different storage conditions (ambient $25^{\circ} \mathrm{C}$ and $60 \% \mathrm{RH}$ and $35^{\circ} \mathrm{C}$ and $75 \% \mathrm{RH}$ ) and the five lengths of storage from zero to 180 days. The tests were done in triplicate for each sample and mean values determined. Statistical Analysis System (SAS Version 9) was used for statistical analysis. Differences at $p \leq 0.05$ were considered significant.

\section{Results and Discussion}

\section{Moisture content}

Moisture content of ASCF increased with increase in storage period irrespective of the packaging materials and storage condition (Figure $1(\mathrm{a}, \mathrm{b}$, and $\mathrm{c})$ ). Dried products are sensitive to moisture variations [10]. According to Muzaffar K, et al. [11] increase in moisture content of the product with increase in environmental relative humidity is a characteristic of amorphous materials rich in hydrophilic. Uchechukwu-Agua $\mathrm{AD}$, et al. [12] indicated that, hygroscopic products absorb moisture from the environment while exposed to the atmosphere. The hygroscopic nature of ASCF therefore, and presence of carbohydrates and protein which are hydrophilic in nature lead to increase in moisture absorption with increase in storage

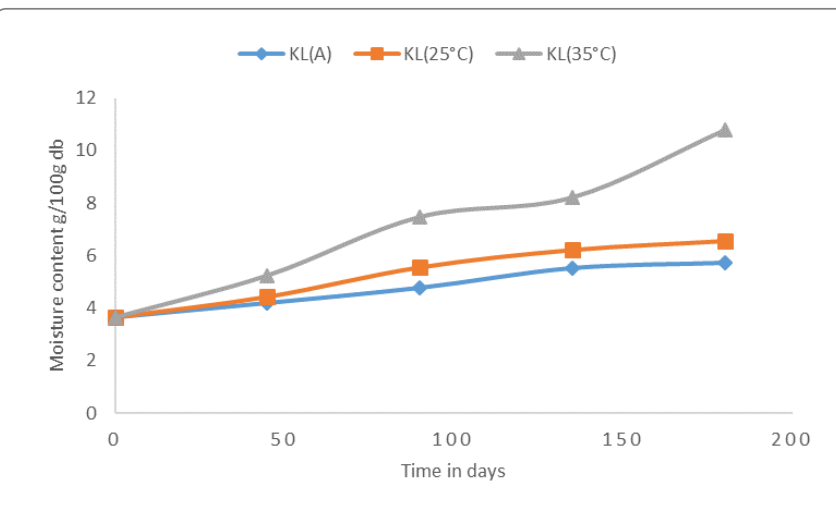

Figure 1(a): Moisture content of ASCF packaged in kraft paper at ambient, $25^{\circ} \mathrm{C}, 60 \% \mathrm{RH}$ and $35^{\circ} \mathrm{C}, 75 \% \mathrm{RH}$ storage conditions. 


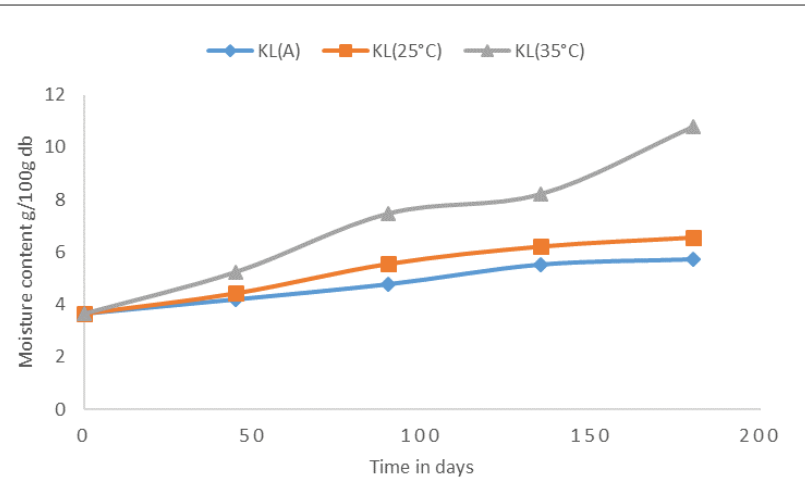

Figure 1(b): Moisture content of ASCF packaged in kraft paper with polyethylene lining at ambient, $25^{\circ} \mathrm{C}$ and $60 \% \mathrm{RH}$ and $35^{\circ} \mathrm{C}$ and $75 \%$ $\mathrm{RH}$ storage conditions.

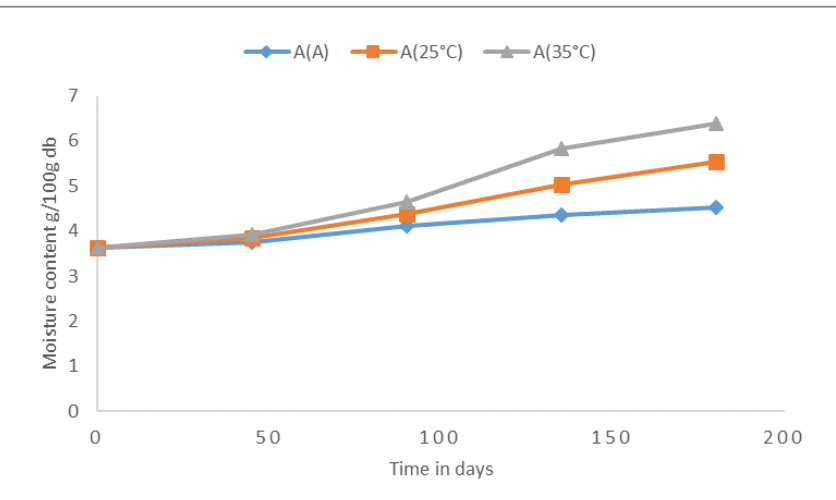

Figure 1(c): Moisture content of ASCF packaged in aluminum pouch at ambient, $25^{\circ} \mathrm{C}$ and $60 \% \mathrm{RH}$ and $35^{\circ} \mathrm{C}$ and $75 \% \mathrm{RH}$ storage conditions.

relative humidity. The increase in moisture content with storage varied with storage condition. Samples stored at $35^{\circ} \mathrm{C}$ and $75 \% \mathrm{RH}$ had significantly $(\mathrm{p}<0.05)$ higher increase in moisture content compared to those stored at $25^{\circ} \mathrm{C}, 60 \% \mathrm{RH}$ and ambient conditions.

This can be attributed to higher relative humidity difference hence higher rate of moisture migration into the packaged product. Due to concentration gradient between the storage environments and the packaged product, migration of water continues until an equilibrium is achieved [13]. This was in agreement with previous study that was carried out on cassava flour where moisture content of the flour increased with storage under high relative humidity [12]. The findings also agreed with a study that was carried out on 3 powders which included wheat flour, tea powder and whey permeate where moisture increased significantly as the storage relative humidity increased [14]. Moisture content was also reported to increase in potato crisps as storage temperature increased [15]. There was variation in moisture content among the packaging materials. Aluminum pouch package was found to be the most effective in controlling moisture migration compared to kraft paper with polyethylene lining and kraft paper. Samples packaged in kraft paper had the highest moisture increase after 180 days of storage from $3.64 \%$ to $7.27 \%$ at ambient condition, $8.14 \%$ at $2^{\circ} \mathrm{C}$ and $60 \% \mathrm{RH}$ and $11.99 \%$ at $35^{\circ} \mathrm{C}$ and $75 \%$ RH. Samples packaged in aluminum pouch had the least moisture content increase with its highest being $6.38 \%$ for samples stored at $35^{\circ} \mathrm{C} ; 75 \% \mathrm{RH}$ after 180 days storage. The variation in moisture content of these

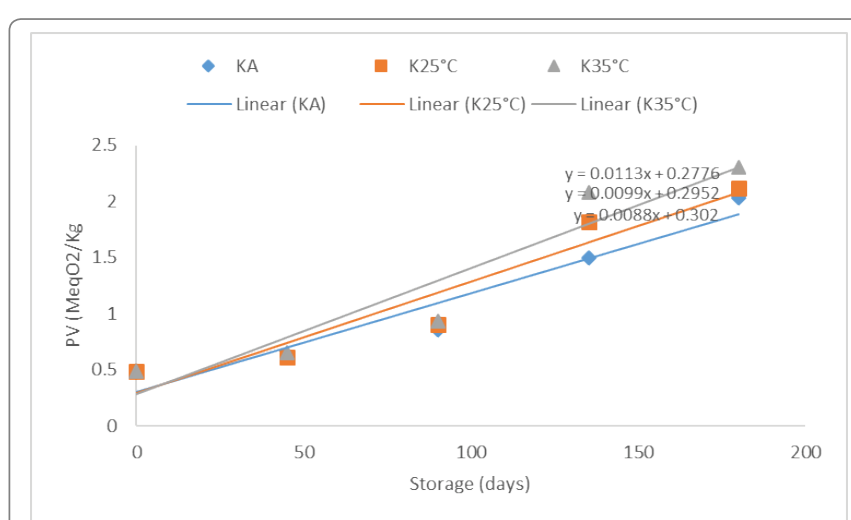

Figure 2: Change in peroxide values ( $\mathrm{PV}$ meqO2/kg) of ASCF stored for 180 days at ambient $(\Delta), 25^{\circ} \mathrm{C}(\square)$ and $35^{\circ} \mathrm{C}(\Delta)$ and packaged in kraft paper.

products could be directly related to the water vapor permeability of the packaging materials. Packaging materials differ in degree of permeation to small molecules like water vapor, and gases. The transfer of the small molecules through the package therefore, ranges from high to low depending on the barrier properties of the material [13]. Similar variation with packaging have been reported in previous studies done on cassava flour, potato crisps and wheat flour [12,14,15].

Shelf life stability of dry products is majorly influenced by moisture content hence making it a vital parameter [16]. The change in moisture is due to water migration from the environment through the packaging material to the product which is influenced by temperature, relative humidity and permeability of the package $[13,17]$. High moisture content may favors enzymatic hydrolysis of the fat and microbial growth in food products [16]. Storage condition and packaging among other factors influence the moisture content of food. Moisture content is an important determinant of shelf life as it is associated with microbial spoilage. Higher level of moisture increases the rate of microbial spoilage in food. Determination of moisture content has been used in some instances to determine the effectiveness of storage conditions $[15,18]$. According to East African Standards, processed cereal based foods for infants and children moisture content maximum limit is $4 \%$. In the current study aluminum pouch maintained moisture level below or at acceptable limit in ambient condition for the whole storage period of 180 days. At $25^{\circ} \mathrm{C} ; 60 \% \mathrm{RH}$ the moisture limit was maintained up to 135 days storage period while at $35^{\circ} \mathrm{C}, 75 \% \mathrm{RH}$ was 90 days. Kraft paper with polyethylene lining maintained the required moisture content for only up to 45 days at $35^{\circ} \mathrm{C} ; 75 \% \mathrm{RH}, 90$ days at $25^{\circ} \mathrm{C} ; 60 \% \mathrm{RH}$ and 135 days at ambient storage condition. Kraft paper did not maintain the maximum moisture content limit for samples stored at $35^{\circ} \mathrm{C} ; 75 \% \mathrm{RH}$ even at the first sampling period of 45 days. At $25^{\circ} \mathrm{C} ; 60 \% \mathrm{RH}$ the moisture limit was maintained up to 45 days storage period while at ambient condition the moisture limit was maintained up to 90 days. A three way analysis of variance was run to examine the effect of packaging, storage condition and storage duration on moisture content of ASCF. There was significant three-way interaction, ( $\mathrm{p} \leq 0.05$ ) indicating that packaging, storage condition and storage duration influenced moisture content of the product.

Butt MS, et al. [16] also reported that the moisture content was affected significantly by storage, treatments, packaging and their interaction.

Just like other dry food products, ASCF require protection against moisture as it may become unacceptable with moisture increase. In 
Table 1: Mean peroxide values (meq $\mathrm{O}_{2} / \mathrm{kg}$ oil) of amaranth sorghum complementary food stored for up to 180 days in three different types of packaging stored in three different storage conditions.

\begin{tabular}{|c|c|c|c|c|c|}
\hline \multirow{2}{*}{ Storage condition } & \multicolumn{5}{|c|}{ Storage time in days } \\
\hline & 0 & 45 & 90 & 135 & 180 \\
\hline \multicolumn{6}{|c|}{ Kraft paper } \\
\hline Ambient condition & 0.49 & 0.61 & 0.85 & 1.49 & 2.03 \\
\hline $25^{\circ} \mathrm{C} 60 \% \mathrm{RH}$ & 0.49 & 0.61 & 0.9 & 1.82 & 2.11 \\
\hline $35^{\circ} \mathrm{C} 75 \% \mathrm{RH}$ & 0.49 & 0.65 & 0.93 & 2.08 & 2.31 \\
\hline \multicolumn{6}{|c|}{ Kraft paper from polyethylene lining } \\
\hline Ambient condition & 0.49 & 0.56 & 0.77 & 1.03 & 1.88 \\
\hline $25^{\circ} \mathrm{C} 60 \% \mathrm{RH}$ & 0.49 & 0.58 & 0.84 & 1.22 & 1.87 \\
\hline $35^{\circ} \mathrm{C} 75 \% \mathrm{RH}$ & 0.49 & 0.62 & 0.9 & 1.69 & 2.12 \\
\hline \multicolumn{6}{|c|}{ Aluminum pouch } \\
\hline Ambient condition & 0.49 & 0.53 & 0.76 & 1.03 & 1.54 \\
\hline $25^{\circ} \mathrm{C} 60 \% \mathrm{RH}$ & 0.49 & 0.53 & 0.84 & 1.22 & 1.87 \\
\hline $35^{\circ} \mathrm{C} 75 \% \mathrm{RH}$ & 0.49 & 0.59 & 0.84 & 1.35 & 1.89 \\
\hline
\end{tabular}

this study, ASCF stored in aluminum pouch minimized increase in moisture as compared to Kraft paper with polyethylene lining and Kraft paper. Moisture migration can be stopped by either reducing the environmental storage humidity or using moisture-barrier packaging material for storage of product in environment of fluctuating atmospheric conditions [19].

\section{Peroxide value}

In the present study, peroxide value (PV) was used to monitor the ASCF oil quality with increase in storage time packaged in different packaging material and stored in three different storage conditions. Changes in PV of stored ASCF are shown in figure 2. Results show that oil of ASCF before storage had a PV of 0.487 meq $\mathrm{O}_{2} / \mathrm{Kg}$ which was lower than what was reported by Gamel TH, et al. [20] of 1.00meq $\mathrm{O}_{2} / \mathrm{Kg}$ for freshly extracted amaranth seed oil. It is an indication that some primary oxidation had taken place before storage of ASCF. This may have been due to heat processing during drying and extrusion and/or exposure of the grains to oxygen when drying [21]. Variation in initial PV may be due to difference in grain processing and also oil extraction process. Fresh coconut oil was found to have PV between 0.24 and $0.49 \mathrm{meqO}_{2} / \mathrm{Kg}$ [22]. According to table 1, although slowly, PV of ASCF samples continually increased during the entire storage period regardless of the storage condition and packaging used.

Lipid oxidation rates are directly related to temperature [23]. In this study, PV increase was highest in samples stored at $35^{\circ} \mathrm{C}$. A PV of $2.31 \mathrm{meq} \mathrm{O}_{2} / \mathrm{Kg}$ was the highest recorded among all the samples. At all the different sampling stages in the three storage environments, increase in PV based on packaging material was in the order of Kraft paper $>$ Kraft paper with polyethylene lining $>$ Aluminum pouch. Packaging materials differ in permeability to environmental factors that may affect the rate of fat oxidation. Light, oxygen and water activity among others influence the rate of fat oxidation [24] exposure to light and oxygen increases the rate of fat oxidation [25]. Water activity also influences the rate of oxidation whereby from $0.3-0.8 a_{w}$ $\mathrm{S}$ the rate of oxidation increases due to dissociation of catalysts as well as the mobility of oxygen and metal ions hence increasing the rate of oxidation of lipids [26]. Analysis of variance showed that the interaction between the effect of package and storage condition on the $\mathrm{PV}$ was not significant $(\mathrm{P}=0.9902)$. However the storage period had a significant effect on PV $(\mathrm{P}=0.000)$ whereby $\mathrm{PV}$ was seen to increase significantly with increase in storage period regardless of the storage condition and package used.

Although there was continuous increase in PV with storage time of ASCF, results revealed that the product had good oxidation stability. This is because 2.3 meq $_{2} / \mathrm{Kg}$ was the highest PV obtained after 180 days storage. A product with PV below $5 \mathrm{meq} \mathrm{O}_{2} / \mathrm{kg}$ is classified at low oxidation state, that between 5 and 10 meq $\mathrm{O}_{2} / \mathrm{kg}$ at moderate oxidation and above 10 meq $\mathrm{O}_{2} / \mathrm{kg}$ is classified at high oxidation state. The PV limit of refined oil according to East African Standard is 10 meq $\mathrm{O}_{2} / \mathrm{kg}$ (EAS 795:2013). Codex gives a general PV limit of $15 \mathrm{meq} / \mathrm{kg}$ for virgin oils [27]. Therefore at 180 days storage even at $35^{\circ} \mathrm{C}$, ASCF can be classified at low oxidation state as its PV was not above the limit. Amaranth seed oil is considered to be very stable even without addition of antioxidants according to a study that was carried out on oxidation stability of amaranth oil [28]. Gamel TH, et al. [20], found that amaranth oil had good oxidation stability better than sunflower oil.

According to East African Standards on processed cereal based foods for infants and young children, the formulated product should be free from rancid or musty odor or flavor [29]. Frankel EN [30] reported that acidity and a rancid taste often started to be noticeable in foods when peroxide values were between 20 to $40 \mathrm{meqO}_{2} / \mathrm{Kg}$. In this study, the highest was $2.31 \mathrm{meq} \mathrm{O}_{2} / \mathrm{Kg}$. To predict the shelf life of the flour, $10 \mathrm{meqO}_{2} / \mathrm{Kg}$ was taken as a quality reference estimation of a maximum acceptable PV. This limit was established using the East African Community Standard 795: 2013 (2013), applicable for refined oils. Linear equation of a plot of $\mathrm{PV}\left(\mathrm{meqO}_{2} / \mathrm{kg}\right)$ versus time in days figure 2 was used to predict the shelf life of ASCF stored in different storage conditions.

Results showed that, samples packaged in kraft paper and stored at $35^{\circ} \mathrm{C}$ could last for 860 days, at $25^{\circ} \mathrm{C}, 980$ days, and at ambient condition, 1102days. Considering that samples packaged in $\mathrm{Kraft}$ paper had the highest PV, it can be concluded that ASCF is shelf life stable in regard to fat oxidation.

\section{Conclusion and Recommendation}

Amaranth sorghum grains complementary food packaged in aluminum pouch can last for 180 days without any major changes of moisture content and peroxide levels at ambient and $25^{\circ} \mathrm{C}, 60 \% \mathrm{RH}$ storage conditions. Storage in Kraft paper with polyethylene lining and kraft paper led to higher increase in moisture content above the recommended maximum limit $4 \%$ for processed cereal based foods for infants and children hence a shorter shelf life. Overall, it is recommended that the product be stored below $25^{\circ} \mathrm{C}$ with careful consideration given to the moisture content of the atmosphere and the type of package.

\section{Acknowledgement}

We are grateful to Jomo Kenyatta University of Agriculture and Technology for financial support during the research.

\section{References}

1. Gernah DI, Ariahu CC, Ingbain EK, Sengev Al (2011) Storage and Shelf life evaluation of food formulations from malted and fermented maize (zea mays $L$.) fortified with defatted sesame (Sesamunindicum L.) flour. Nigerian J Nutr Sci 32: 45-54.

2. Singh TK, Cadwallader KR (2004) Ways of measuring shelf-life and spoilage. In: Steele R (eds) Understanding and measuring the shelflife of food. Woodhead Publishing 165-183. 
3. Prchalová J, Čížková H, Ševčík R, Hanušová K, Rajchl A (2016) Evaluation of shelf-life of fruit baby food. Agro Res 14: 556-568.

4. Okoth JK, Ochola SA, Gikonyo NK, Makokha A (2017) Development of a nutrient-dense complementary food using amaranth-sorghum grains. Food Sci Nutr 5: 86-93.

5. Dalpe JF, Lloyd-George I (2012) Laminate for packaging hygroscopic materials, pouches made there from, and method for manufacturing same. USA.

6. Vanhanen LP, Savage GP (2006) The use of peroxide value as a measure of quality for walnut flour stored at five different temperatures using three different types of packaging. Food chem 99: 64-69.

7. Robertson GL (2009) Food packaging and shelf life: a practical guide. CRC Press 404.

8. George W Latimer (2012) Official Methods of Analysis. 19 th $^{\text {th }}$ Edition, Association of Official Analytical Chemists, USA.

9. David Firestone (1998) Official methods and recommended practices of the American Oil Chemists' Society. American Oil Chemists' Society, Champaign, IL, USA.

10. Al-Muhtaseb AH, McMinn WAM, Magee TRA (2002) Moisture sorption isotherm characteristics of food products: a review. Food Bioproducts Processing 80: 118-128.

11. Muzaffar K, Kumar P (2016) Moisture sorption isotherms and storage study of spray dried tamarind pulp powder. Powder Technol 291: 322-327.

12. Uchechukwu-Agua AD (2015) Effects of packaging and storage condition on functional properties and quality attributes of cassava flour. Doctoral dissertation, Stellenbosch, Stellenbosch University.

13. Siracusa V (2012) Food packaging permeability behaviour: A report. Inter J Polymer Sci 2012: 1-11.

14. Iqbal T, Fitzpatrick JJ (2006) Effect of storage conditions on the wall friction characteristics of three food powders. J Food Eng 72: 273 280

15. Abong GO, Okoth MW, Imungi JK, Kabira JN (2011) Effect of packaging and storage temperature on the shelf life of crisps from four Kenyan potato cultivars. Am J Food Technol 6: 882-892.

16. Butt MS, Nasir M, Akhtar S, Sharif K (2004) Effect of moisture and packaging on the shelf life of wheat flour. Inter J Food Safety 4: 1-6.

17. Adebola MO, Dadi-Mamud NJ, Nusa Halima MK (2014) The effects of packaging materials of shelf-life stability of Garri bought from markets in Lapai Niger State Nigeria. J Appl Environ Microbiol 2: 1215.

18. Alam MS, Alam MS, Islam MR, Begum MF, Sarkar MA, et al. (2001) Abundance of fungal flora in relation to moisture content and storage period in different types of poultry feed ingredients. Pak J Biol Sci 4: 1194-1197.

19. Hotchkiss JH (1997) Food-packaging interactions influencing quality and safety. Food Addit Contam 14: 601-607.

20. Gamel TH, Mesallam AS, Damir AA, Shekib LA, Linssen JP (2007) Characterization of amaranth seed oils. J food lipids 14: 323-334.

21. Kaleem A, Aziz S, Iqtedar M, Abdullah R, Aftab M, et al. (2015) Investigating changes and effect of peroxide values in cooking oils subject to light and heat. FUUAST J Biol 5: 191-196.

22. Moigradean D, Poiana MA, Gogoasa I (2012) Quality characteristics and oxidative stability of coconut oil during storage. J Agro Processes Technol 18: 272-276.

23. Flick GJ, Hong GP, Knobl GM (1992) Lipid oxidation of seafood during storage. FAO, USA.

24. Hu M, Jacobsen C (2016) Oxidative stability and shelf life of lowmoisture foods. In: Min Hu, Charlotte Jacobsen (Eds) Oxidative Stability and Shelf Life of Foods Containing Oils and Fats. Elsevier 313-371.

25. StarkC, McNeil DL, Savage GP (2000) The effect of storage conditions on the stability of peroxide values of New Zealand grown walnuts. In: Proceedings of the Nutri Society of New Zealand 25: 43-54.

26. Bell L (2002) Water Activity and Reaction Rates/Physical Properties/ Shelf-Life. In: IFT Fundamentals of Water Activity Short Course presented at the 2002 Annual Conference of the Institute Food Technologists, Anaheim, CA.

27. Codex Alimentarius (1991) Guidelines on formulated supplementary foods for older infants and young children CAC/GL08-1991. Rome, Italy.

28. Santiago DP, Lauro CPA, Torres TJ, Rodriguez TR, Romero GDJ, et al (2012) Accelerated Shelf Life Tests of Amaranth Oil (Amaranthus hypochondriacus). Las Vegas, USA.

29. East Africa Standard (EAS) (2013) Processed cereal-based foods for infants and children-Specification. $2^{\text {nd }}$ Edition, East Africa Community.

30. Frankel EN (1980) Lipid oxidation. Prog Lipid Res 19: 1-22. 